\title{
The Structural Transformation of Manufacturing Industry in Northeast China and the Solution to Its Economic Growth
}

\author{
Shuai Zhu ${ }^{\text {a }}$, Shuomin Zhao ${ }^{\mathrm{b}}$, Tianshuai Xu ${ }^{\mathrm{c}}$, Wanhong $\mathrm{Li}^{\mathrm{d}}$ \\ Harbin Engineering University, Harbin, 150001, China. \\ a15210829065@163.com, bzhaosm0912@126.com, cxvts@foxmail.com, dliwanhong@hrbeu.edu.cn
}

Keywords: Northeast China, old industrial base, state-owned enterprise reform, industrial innovation.

\begin{abstract}
The Party Central Committee and the State Council set out from the strategic goal of building a well-to-do society in an all-round way and take the inevitable requirements of a new path of industrialization and put forward the strategic policy of rejuvenating the old industrial base in the northeast. The purpose is to grasp this historic opportunity to realize the revitalization of the northeast old industrial base and the overall development of the social economy, promote the combination of theory and reality, and provide theoretical support for the revitalization of the old industrial base in the northeast. Under the background of science and technology in the new century, manufacturing bases play an important role in the realization of the goal of fully building a well-off society and realizing the third-step strategic goal of economic development. It also played an important role in the fall of socialist ideas with Chinese characteristics in the new era of Xi Jinxing.
\end{abstract}

\section{The Overall Status of The Manufacturing Industry in Northeast China}

After entering 2003, the structural gap between the three industries gradually opened. While the primary industry is developing steadily, the secondary industry still occupies a relatively dominant position. However, due to the support of the national policy, the rapid development of the tertiary industry has gradually approached the secondary industry, and the gap has moved towards a year-by-year reduction.

Due to the support of national policies, the development of the tertiary industry has been accelerated, the pace of industrial restructuring in the Northeast has been accelerated year by year, and the industrial structure has become more reasonable, which has created a favorable industrial environment for economic development in the Northeast.

In 2014, the economic growth rates in the northeastern region were 5.8\% in Liaoning Province, $5.6 \%$ in Heilongjiang Province and 6.5\% in Jilin Province, all lower than the national average growth rate of $7.4 \%$. In the first quarter of 2015, the economic growth rate of Liaoning Province was $1.9 \%$, 4.8\% in Heilongjiang Province, and 5.8\% in Jilin Province, all still below the national average of 7\%. This means that both the overall economic development in the northeast region and the manufacturing industry, which is the backbone of the northeast region, are facing tremendous downward pressure.

Since the 21st century, under the promotion of the national strategy of revitalizing the northeast old industrial base, the manufacturing industry in the northeast has re-emerged. The capacity of the major industries has expanded rapidly and the construction of industrial bases has been accelerating. Many large-scale industrial clusters have formed in the key areas of manufacturing, and the trend of agglomeration of heavy chemical industry represented by equipment manufacturing industry is evident.

Based on the industrial and manufacturing value-added, from the data point of view, the output value of industry and manufacturing in the three provinces has risen steadily since 2003. Although there are fluctuations in the middle, there has been no major impact. Among them, the added value of manufacturing in the three provinces fell sharply in 2009 and was related to the global financial crisis. 
In Liaoning, the manufacturing value of the pillar industries in 2014 was negative, which is also one of the manifestations of the economic recession in Northeast China.

Table 1. Industrial added value and added value of manufacturing in three provinces in Northeast

China

\begin{tabular}{|c|c|c|c|c|c|c|c|c|c|}
\hline \multirow{3}{*}{ year } & \multicolumn{3}{|c|}{ Liaoning } & \multicolumn{3}{|c|}{ Jilin } & \multicolumn{3}{|c|}{ Heilongjiang } \\
\hline & \multirow{2}{*}{$\begin{array}{l}\text { Industrial } \\
\text { added } \\
\text { value } \\
(100 \\
\text { million } \\
\text { yuan) }\end{array}$} & \multirow{2}{*}{$\begin{array}{l}\text { The } \\
\text { added } \\
\text { value of } \\
\text { manufac } \\
\text { turing } \\
\text { industry } \\
(100 \\
\text { million } \\
\text { yuan) }\end{array}$} & \multirow{2}{*}{$\begin{array}{c}\text { Proporti } \\
\text { on } \\
\text { (manufa } \\
\text { cturing } \\
\text { value } \\
\text { added / } \\
\text { industria } \\
\text { l added } \\
\text { value)) }\end{array}$} & \multirow{2}{*}{$\begin{array}{l}\text { Industri } \\
\text { al added } \\
\text { value } \\
(100 \\
\text { million } \\
\text { yuan) }\end{array}$} & \multirow{2}{*}{$\begin{array}{c}\text { The } \\
\text { added } \\
\text { value of } \\
\text { manufac } \\
\text { turing } \\
\text { industry } \\
\text { (100 } \\
\text { million } \\
\text { yuan) }\end{array}$} & \multirow{2}{*}{$\begin{array}{l}\text { Proporti } \\
\text { on } \\
\text { (manufa } \\
\text { cturing } \\
\text { value } \\
\text { added / } \\
\text { industri } \\
\text { al added } \\
\text { value) }\end{array}$} & \multirow{2}{*}{$\begin{array}{l}\text { Industria } \\
\text { l added } \\
\text { value } \\
(100 \\
\text { million } \\
\text { yuan) }\end{array}$} & \multirow{2}{*}{$\begin{array}{l}\text { The } \\
\text { added } \\
\text { value of } \\
\text { manufa } \\
\text { cturing } \\
\text { industr } \\
\text { y (100 } \\
\text { million } \\
\text { yuan) }\end{array}$} & \multirow[t]{2}{*}{$\begin{array}{c}\text { Proportion } \\
\text { (manufacturin } \\
\text { g value added } \\
\text { / industrial } \\
\text { added value) }\end{array}$} \\
\hline & & & & & & & & & \\
\hline 2003 & 2556.82 & 1185.45 & 0.46 & 930.74 & 662.12 & 0.71 & 1874.8 & 455.37 & 0.24 \\
\hline 2004 & 2680.41 & 1754.33 & 0.65 & 1060.35 & - & - & 2242.32 & 494.6 & 0.22 \\
\hline 2005 & 3401.8 & 2257.29 & 0.66 & 1169.39 & 820.39 & 0.7 & 2696.3 & 893.12 & 0.33 \\
\hline 2006 & 4017.02 & 3095.68 & 0.77 & 1514.36 & 975.04 & 0.64 & 3049.04 & 625.03 & 0.2 \\
\hline 2007 & 4892.45 & 4212.15 & 0.86 & 2079.79 & 1520.42 & 0.73 & 3326.9 & 849.9 & 0.26 \\
\hline 2008 & 6359.43 & 5398.54 & 0.85 & 2491.3 & 1394.72 & 0.56 & 3866.43 & 1232.2 & 0.32 \\
\hline 2009 & 6925.63 & 1563.76 & 0.23 & 2926.65 & 711.05 & 0.24 & 3549.73 & 528.08 & 0.15 \\
\hline 2010 & 8789.27 & 8176.58 & 0.93 & 3755.31 & 3433.06 & 0.91 & 4429.31 & 745.04 & 0.17 \\
\hline 2011 & 10696.5 & 4515.8 & 0.42 & 4531.95 & 3108.21 & 0.69 & 5234.64 & 1135.3 & 0.22 \\
\hline 2012 & 11605.1 & 9326.66 & 0.8 & 5482.48 & 3733.72 & 0.68 & 5240.65 & 1074.79 & 0.21 \\
\hline 2013 & 12300.7 & 3554.4 & 0.29 & 6080.28 & 2096.28 & 0.34 & 5090.34 & 1392.3 & 0.27 \\
\hline 2014 & 12656.8 & -2578.5 & -0.2 & 6492.88 & 3235.64 & 0.49 & 4783.88 & 142.32 & 0.03 \\
\hline
\end{tabular}

Source: NPC Economic Forum

From the point of view of the ratio of the added value of the manufacturing industry over the years, the manufacturing industry gradually dominated the industrial industry after 2003, and the manufacturing industries in the three northeastern provinces have developed rapidly and have driven the development of the industry.

Through the above table, we can clearly see that the trend of the proportion of manufacturing industry in the industrial industry after 2003 has risen first and then declined. To sum up the reasons for this, we found that in 2003, the state introduced a series of policy measures to revitalize the old industrial base in the northeast, and the first round of revitalization policies has achieved remarkable results. From 2003 to 2012, the total production value of the old industrial base in the northeast more than quadrupled, with an average annual growth rate of $12.7 \%$. However, since 2010, the Chinese economy has faced the challenges posed by the "three-phase superposition" of shifting gears for growth, painstaking adjustment of economic structure, and the digestion period of the previous stimulus policies. There has been a general difficulty in the lack of economic growth in all regions.

\section{Main Issues in the Development of Manufacturing in Northeast China}

\subsection{Industrial Agglomeration Imbalance.}

The economy, population, investment environment and other aspects are the important influencing factors for the formation of an industrial space agglomeration in Shenyang, Dalian, Changchun and Harbin. The labor-intensive industries in the manufacturing industry in the northeast old industrial base have typical unbalanced development. The negative externalities caused by the "congestion effects" of a series of industries caused by it have caused the old industrial bases in Northeast China to be marginalized in the process of industrialization in China.

\subsection{The Market Has A Low Degree of Development.}

The development environment and conditions of market entities will surely promote the optimization of industrial structure. A large number of state-owned large and medium-sized 
industrial enterprises have not really upgraded, making the Northeast China a new type of industrial base. This will inevitably lead to real market players, lack of self-restraint, self-development and comprehensive social, coordinated, and sustainable development, accelerating the capacity of the Northeast, and slow development of the private economy.

Table 2. Industrial manufacturing scale

\begin{tabular}{|c|c|c|c|c|c|c|c|c|c|}
\hline \multirow[t]{2}{*}{ Year } & \multicolumn{9}{|c|}{ Industrial added value (100 million yuan) } \\
\hline & & & & 03 & & 2009 & & 2014 & \\
\hline province & Liaoning & Jilin & $\begin{array}{l}\text { Heilon } \\
\text { gjiang }\end{array}$ & Liaoning & Jilin & $\begin{array}{l}\text { Heilong } \\
\text { jiang }\end{array}$ & Liaoning & Jilin & Heilongjiang \\
\hline $\begin{array}{l}\text { Agricultural and food } \\
\text { processing industry }\end{array}$ & 57.18 & 79.12 & 37.73 & 452.99 & 219.61 & 144.54 & 369.07 & 114.3984 & 103.9838 \\
\hline Food manufacturing & -2.4 & -48.7 & 15.65 & 98.54 & 24.00 & 76.84 & -52.09 & 26.3607 & 53.456 \\
\hline $\begin{array}{c}\text { Beverage } \\
\text { manufacturing }\end{array}$ & 2.13 & 8.85 & 11.87 & 62.84 & 53.34 & 13.49 & -20.42 & 27.8539 & 3.8112 \\
\hline $\begin{array}{c}\text { Tobacco } \\
\text { manufacturing }\end{array}$ & 6.53 & 1.72 & -5.64 & 2.06 & 10.57 & 10.87 & 5.86 & $\begin{array}{c}6030.397 \\
5\end{array}$ & -8.1454 \\
\hline Textile Industry & 18.74 & 1.71 & 3.95 & 50.72 & 10.25 & -3.27 & -51.61 & 24.9251 & 8.4112 \\
\hline $\begin{array}{l}\text { Textile, Apparel, } \\
\text { Shoes and Cap } \\
\text { Manufacturing }\end{array}$ & - & - & - & 6.17 & 7.63 & 2.62 & 207.78 & 14.8642 & 1.9585 \\
\hline $\begin{array}{l}\text { Paper and paper } \\
\text { products industry }\end{array}$ & 3.71 & 2.61 & -4.97 & 43.76 & -1.99 & -1.46 & -82.53 & 19.7523 & -4.1206 \\
\hline $\begin{array}{l}\text { Petroleum processing, } \\
\text { coking and nuclear } \\
\text { fuel processing }\end{array}$ & 233.34 & 1.52 & 83.57 & 280.85 & 0.00 & 12.17 & 14.19 & 8.8777 & -88.4259 \\
\hline $\begin{array}{l}\text { Chemical raw } \\
\text { materials and } \\
\text { chemical products } \\
\text { manufacturing }\end{array}$ & 54.81 & 71.96 & 11.45 & 253.71 & 42.41 & -16.80 & 229.59 & 45.7992 & 13.636 \\
\hline $\begin{array}{l}\text { Pharmaceutical } \\
\text { manufacturing }\end{array}$ & 11.93 & 14.97 & 13.57 & 40.24 & 94.00 & 23.13 & 57.15 & 279.4003 & 20.8712 \\
\hline $\begin{array}{l}\text { Chemical fiber } \\
\text { manufacturing }\end{array}$ & -0.98 & 4.54 & 3.19 & -18.31 & 8.10 & -1.46 & -3.59 & 495.2527 & 0.7224 \\
\hline $\begin{array}{l}\text { Non-metallic mineral } \\
\text { products industry } \\
\text { Ferrous metal }\end{array}$ & 41.28 & 13.12 & 2 & 399.82 & 217.85 & 47.20 & 165.71 & 111.5503 & -11.6541 \\
\hline $\begin{array}{l}\text { smelting and rolling } \\
\text { processing industry }\end{array}$ & 269.27 & 16.67 & 22.75 & 92.12 & -57.85 & -15.54 & 340.38 & -12.239 & 139.2003 \\
\hline $\begin{array}{l}\text { Non-ferrous metal } \\
\text { smelting and rolling } \\
\text { processing industry }\end{array}$ & 21.74 & 0.72 & -0.63 & 59.23 & -0.93 & -8.97 & 140.72 & 21.259 & -3.1081 \\
\hline $\begin{array}{l}\text { Metal products } \\
\text { industry }\end{array}$ & 22.79 & -0.09 & 4.44 & 114.11 & 42.28 & -0.41 & -55.02 & -3.069 & 7.8071 \\
\hline $\begin{array}{l}\text { General equipment } \\
\text { manufacturing }\end{array}$ & 102.95 & -2.38 & 20.97 & 555.58 & 26.12 & -28.54 & 478.19 & 37.1078 & 102.7073 \\
\hline $\begin{array}{l}\text { Special equipment } \\
\text { manufacturing }\end{array}$ & 54.38 & 7.86 & 29.83 & 283.16 & 54.05 & 20.53 & 115.61 & 34.7749 & 103.7915 \\
\hline $\begin{array}{l}\text { Transportation } \\
\text { equipment } \\
\text { manufacturing }\end{array}$ & 112.44 & $\begin{array}{c}301.9 \\
9\end{array}$ & 27.41 & 348.75 & 784.29 & 47.93 & 325.92 & 450.5181 & 47.0219 \\
\hline $\begin{array}{l}\text { Electrical machinery } \\
\text { and equipment } \\
\text { manufacturing }\end{array}$ & 41.11 & -2.31 & 3.24 & 276.45 & 35.85 & $\begin{array}{c}17258.0 \\
0\end{array}$ & -173.7 & 45.0096 & 221.1403 \\
\hline $\begin{array}{l}\text { Communications } \\
\text { Equipment, } \\
\text { Computers and Other } \\
\text { Electronic Equipment } \\
\text { Manufacturing }\end{array}$ & 42.5 & -5.51 & 3.01 & 22.62 & 6.97 & 3.29 & -31.31 & -3.131 & 3.7019 \\
\hline $\begin{array}{l}\text { Instrumentation and } \\
\text { culture, office } \\
\text { machinery } \\
\text { manufacturing }\end{array}$ & 11.91 & 1.31 & -2.91 & 29.00 & 3.91 & 0.19 & -28.16 & 4.2947 & 2.3527 \\
\hline
\end{tabular}




\subsection{The Transition of State-Owned Enterprises Is Very Slow, and the Private Economy Is Lack of Vitality.}

The state-owned enterprises in the equipment manufacturing industry in the Northeast China are concentrated, and the contradictions and problems faced by the state-owned enterprises during the transition from the planned economy to the market economy are also particularly prominent. The historical fact that the state-owned enterprises are highly concentrated in the northeast region has squeezed the development space of the private economy to a certain extent, presenting an embarrassing situation of "difficult to grow grass under the big tree".

\subsection{The Loss of Talent.}

Although colleges and universities in the northeastern region are gathered, there is a huge amount of brain drain, making no one available in the northeast, and there are no talents in the enterprise for reform. The graduates were unable to participate in the work at the first time because of the lack of knowledge in learning and the needs of the factories, making the Northeast industry always at a low level.

\subsection{The History of The Company Is Heavy.}

In the process of transformation, the state-owned competitive enterprises have a heavy burden, and they cannot participate in the contradictions and problems existing in the old industrial bases in the northeastern market under equal conditions. There are too many redundant employees in the enterprise. One person needs to support three people, which makes the issue of laid-off and diversion and social security very prominent and causes serious losses for the company.

\section{The Solution}

\subsection{Government Level.}

\subsubsection{Deepen the Reform of State-Owned Enterprises and Promote Structural Adjustment.}

Accelerate the strategic adjustment of the layout and structure of the state-owned economy and state-owned capital must exit competitive areas. We leave space and resources for private enterprises and private enterprises, allowing the manufacturing base to have market competition, concentrating limited resources, and concentrating on important industries related to national security and the lifeblood of the national economy. At the same time, we will improve the quality of state-owned capital and give full play to the advantages of market allocation and non-replacement of private capital. We advocate and implement a national shareholding system. Except for a few companies that are involved in the country's economic lifeline and security, the rest of the enterprises should allow the country to hold shares and buy and sell the remaining shares to achieve diversification of shares. This will allow more private entrepreneurs to enter state-owned enterprises in this way through decision-making, so that state-owned enterprises can understand modern market rules and establish effective corporate governance mechanisms.

\subsubsection{The Combination of Manufacturing Base and City.}

Because the construction and development of the manufacturing base are relatively slow, and the basic facilities are constructed in accordance with the needs of the base, the management model is backward and there is no awareness of managing the city. Therefore, the government should integrate economic structure adjustment and urban management well so that urban planning can be adapted to operational requirements. While optimizing the urban living environment, the government has mobilized the urban infrastructure classified operating stock to absorb the incrementally revitalized urban land assets, maximized the value and economic benefits of the land, and activated urban assets.

\subsubsection{Improve the Social Security System.}

The historical burden of the old industrial base is heavy, and the financial pressure for the establishment of a social security system is great. It is necessary to increase the transfer of central government finances. The social security system must implement national treatment, include joint ventures, foreign-funded enterprise employees, individual and private owners in the social security category, and increase coverage. We established a reliable and stable multi-channel fundraising mechanism for social security funds that is shared by businesses, individuals, and the government. 
This will ease the heavy pressure of relying solely on enterprises to pay social insurance and gradually increase the proportion of social security expenditures in fiscal expenditure. We realized some of the state-owned assets to supplement the insufficiency of social security funds during the reform process, supported the expansion of issuance of shares and other means to raise social security funds to ensure the continued healthy development of social insurance, social assistance and social welfare services.

\subsection{Industry Level.}

\subsubsection{Accelerate Industrial Restructuring and Upgrading and Take A New Path.}

We insist on informatization to promote industrialization, promote industrialization to promote informationization, and develop a new type of industrial road with high technology content, good economic returns, full utilization of human resources, and high resource utilization. We use product innovation to drive technological innovation and give full play to the positive effects of high-tech industries on economic growth. We combine industrialization and informatization to improve technological standards and administrative efficiency so as to improve the overall industrial level of the manufacturing area and its position in the international industrial zone. We actively integrate into the international global production system, undertake intermediate fool projects, improve basic manufacturing facilities in Northeast Province, increase employment in Northeast China, improve the industrial system, and form a certain scale of new international manufacturing bases. This will promote industrial reforms in the province, lay a solid foundation for the reforms, and form an excellent industrial cluster framework.

\subsubsection{Accelerate the Service-Oriented Reform of the Manufacturing Industry.}

We are accelerating the development of manufacturing services, and the service-oriented manufacturing industry means that manufacturing companies must change their value chain from manufacturing-centered to service-centered in order to gain competitive advantage. Manufacturing companies must establish a strategic thinking based on customer service. We regard customer service as the foundation of business development, and provide the concept of providing comprehensive services or solutions to customers throughout the entire process of business operations, and produce cost-effective products based on customer needs. We promoted the deep integration of "two industries” and infiltrated the information network technology into product design, technology research and development, integrated manufacturing, testing and certification, marketing, logistics services and other related links to expand and expand the manufacturing industry.

\subsubsection{Establish an Industrial Cluster.}

Through industrial integration, we have strengthened industrial support and collaboration in the region, accelerated the construction of regional market factors such as capital, information, technology and human resources, and promoted the rational flow of production factors within the region. In this way, an integrated regional economic system with rational allocation of resources, supporting industries and rational division of labor in cities can be formed, providing development space for the construction of modern manufacturing bases and service centers. We have played the role of industrial linkage between well-known brands and large enterprise groups, and gradually extended the industrial chain to gradually form a group of large, medium, and small enterprises with reasonable structures, hierarchical competition, and coordinated development, and to form industrial chains to form industrial clusters. .

\subsubsection{Attract and Train Outstanding Talents.}

In order to adapt to the needs of a technology-based economy, we should advocate and formulate a high-level technical education program that allows for a deep integration of production and education, students really practice, and ultimately make the "good learning" and "useful" seamless connection. . We have strengthened the cultivation and work of talents in Northeast China, actively nurtured high-level talents, and met the needs of opening up and attracting foreign capital outside major manufacturing enterprises in the Northeast manufacturing base. While introducing talents, we must combine the development of enterprises, improve and optimize the employment mechanism, establish a reasonable reward system and guarantee system, and attract and encourage more high-tech talents to come to the Northeast manufacturing base. This can contribute to the economic 
development and manufacturing transformation in the Northeast, and lay a solid foundation for the transformation of manufacturing companies.

\section{Summary}

Due to the long industrial base period in the Northeast China, the decline of the manufacturing industry in recent decades has greatly hit the Northeast economy. And the government wants to accelerate the revitalization, leading to the industrial transformation system has been changing, so that entrepreneurs lose trust in the government, the old investment policy allows foreigners to refuse to stay. This has caused the northeastern region's economic situation, infrastructure construction and living environment to lag behind the rest of the country, resulting in the loss of a large number of talents and a vicious circle. The above mentioned landmark issues put forward by this project provides us with suggestions and solutions. The implementation of these measures will greatly ease the frictions and conflicts that arise between reforms and speed up the reform.

\section{Acknowledgments}

This research was supported by funding from the Philosophy \& Social Science Project of Heilongjiang Province (NO.16JYB04) and the National College Students' innovative training program (NO. 201810217096).

\section{References}

[1]. Mu Junjie. Innovative Thinking on the Rejuvenation of Northeast Old Industrial Base [J] Modern Communication 2016(01).

[2]. Li Han, Li Guangsheng. Community Awareness and the New Development of Old Industrial Bases in Northeast China [J]. Theory of Study 2009 (23)

[3]. Gao Jing. Institutional innovation is the key to revitalizing the northeast old industrial base [J]. Journal of Harbin University of Commerce (Social Sciences Edition) 2004(06).

[4]. Qi Guiqin, Yang Fenghua. On Private Economy and Revitalization of Northeast Old Industrial Base [J].Economic Perspectives.2004 (01).

[5]. The conditions for rejuvenating the old industrial bases in northeast China are ripe [J]. Statistics and Consulting 2003(05).

[6]. Yang Zhangxian, Zhang Hao, Li Chenggu. Study on the urbanization response path of the industrial structure evolution of the northeast old industrial base [J] Journal of Northeast Normal University (Philosophy and Social Sciences).2011(04).

[7]. LAN Land, Shi Wearying. Serving the Construction of the Old Industrial Base in Northeast China, Promoting the Development of Archive Work [J]. Century Bridge 2008 (12).

[8]. Li Chenglong. Comprehensive report on the revitalization and development of major policies in the Northeast Old Industrial Base [J] Theory of Study 2008 (06).

[9]. Zhou Ping, Zhou Bin. The Relationship between Non-traditional Security and the Revitalization of Old Industrial Base in Northeast China [J] Journal of Shenyang University 2007 (01).

[10]. Cao Chengxian. Establishing a New Concept of Development and Advanced Culture Promoting the Revitalization of Old Industrial Bases in Northeast China [J] Liaoning Economic Polytechnic (Journal of Liaoning Economic Management Cadre College) 2007(01). 